ROCZNIKI PEDAGOGICZNE

Tom 11(47), numer $4-2019$

DOI: http://dx.doi.org/10.18290/rped.2019.11.4-8

\title{
KATARZYNA WOŁK
}

\section{ODPOWIEDZIALNE RODZICIELSTWO W KONTEKŚCIE ZMIANY SPOŁECZNEJ}

\section{WPROWADZENIE}

Nieustannie zmieniająca się rzeczywistość skłania do zastanowienia się, jakie obecnie powinno być rodzicielstwo. Współcześnie przybiera ono różne oblicza i stawia przed rodzicem dodatkowe wyzwania. Dzisiejsze tempo życia, problemy zawodowe czy rodzinne znacząco wpływają na postawę ojca/matki. Świadomość, iż trudne sytuacje są i będą się pojawiały w życiu każdego człowieka, jest pierwszym krokiem do podjęcia rodzicielstwa odpowiedzialnego. W prezentowanym artykule zostanie przedstawione rozumienie terminu „odpowiedzialne rodzicielstwo" oraz trudności, z którymi może spotkać się współczesny rodzic. Autorka w tekście odwołuje się do badań naukowych opublikowanych w latach 1998-2000 oraz przedstawia sytuację panującą obecnie w Polsce.

\section{ROZUMIENIE TERMINU „ODPOWIEDZIALNE RODZICIELSTWO”}

„Rodzicielstwo" jest terminem definiowanym przez encyklopedię jako bycie rodzicem - funkcjonowanie w roli rodzica. Barbara Kromolicka (2012, s. 39-51) precyzuje, iż jest to ,stale toczący się proces przemian, którego początków należy szukać w cyklach życia rodzinnego, poczynając od dzieciństwa, przez kształtowanie się cech osobowościowych zachowań i poglądów rodzica do przyjęcia określonej postawy rodzicielskiej oraz stylu wychowawczego". Pojawia się już w momencie poczęcia dziecka, obejmując realizację zadań obliczonych na

Dr KATARZYNA WoŁK - doktor nauk społecznych w zakresie pedagogiki, Zakład Teorii Wychowania, Instytut Pedagogiki, Uniwersytet Marii Curie-Skłodowskiej w Lublinie, ul. Narutowicza 12, 20-004 Lublin; e-mail: katarzyna.wolk@ poczta.umcs.lublin.pl 
stworzenie potomstwu szans na przetrwanie oraz zapewnienie najlepszego rozwoju i osiągnięcia samodzielności. W perspektywie ontogenetycznych stadiów rozwoju rodziny rodzicielstwo wyłania się w trzecim stadium, wraz z pojawieniem się pierwszego dziecka (Brągiel, 2013, s. 13). Termin „rodzicielstwo” w połączeniu z przymiotnikiem „odpowiedzialne” nabiera zupełnie nowego znaczenia, które może być rozumiane na wiele sposobów. Odpowiedzialne, czyli świadome, kompetentne bycie rodzicem. Mała encyklopedia PWN (2000, s. 593) definiuje odpowiedzialność jako „konieczność, obowiązek moralny lub prawny odpowiadania za swoje czyny i ponoszenia konsekwencji”. Stanisław Jedynak (1990, s. 175) określa ją jako właściwość ludzkiego postępowania polegającą na możności lub gotowości do ponoszenia konsekwencji, wzięcia na siebie dobrych i złych skutków własnych poczynań, wynikających ze świadomego działania. Oznacza to, że każdy, kto dokonuje pewnego czynu, ponosi za niego odpowiedzialność - za swoje działanie może być pociągnięty do odpowiedzialności. W celu zrozumienia omawianego zagadnienia na gruncie pedagogiki należy zacząc od jego rozumienia w aspekcie filozoficznym. Analiza słowa „odpowiedzialność” wskazuje potrzebę wyjaśnienia „kto?”, „za co?” i „wobec kogo?” odpowiada. W kontekście rodzicielstwa odpowiedzialność ponoszą rodzice za czyn (działanie), jakim jest poczęcie (zrodzenie) potomstwa, a następnie wychowanie wobec Boga (w przypadku osób wierzących), rodziny i społeczeństwa.

Obecnie dokonuje się radykalna zmiana postrzegania rodzicielstwa i brakuje wrażliwości na wyjątkowość oraz wartość ludzkiego życia. Taka postawa wynika z nadmiernego podkreślania uprawnień jednostki w dziedzinach, które tradycyjnie są zastrzeżone dla powszechnie obowiązujących praw zgodnych z naturą i godnością człowieka, podstawą jego dalszych praw i obowiązków ( $O$ wyzwaniach bioetycznych, przed którymi stoi wspótczesny czlowiek. Dokument przyjęty na 361 . Zebraniu Plenarnym Konferencji Episkopatu Polski 5 marca 2013 r. w Warszawie ).

Odpowiedzialne rodzicielstwo zaczyna się w chwili, gdy pojawia się myśl o poczęciu dziecka i trwa aż do osiągnięcia przez nie dojrzałości. Przy czym każdy kolejny etap charakteryzuje się innymi zadaniami. Najważniejszymi etapami są: poczęcie dziecka, bliski kontakt w okresie prenatalnym i prawidłowy poród, dobre wychowanie oraz wdrażanie do samowychowania. Odpowiedzialne małżeństwo, zanim podejmie współżycie w okresie płodnym, zastanawia się, jaki moment byłby najlepszy na urodzenie dziecka. Odpowiedzialne rodzicielstwo wymaga wiedzy na temat natury płodności pary ludzkiej. Często mówi się o ciążach chcianych (planowanych) i niechcianych (nieplanowanych). W przypadku poczęcia nieplanowanego miarą odpowiedzialnego rodzicielstwa jest przyjęcie 
dziecka z taką samą życzliwością, jak gdyby zapoczątkowanie nowego życia było zamierzone. Jest to również świadomość, że przy każdym akcie współżycia, nawet jeśli dojdzie do nieplanowanego zapłodnienia, para jest otwarta na przyjęcie potomka.

Masud Hoghugh definiuje wystarczająco dobre rodzicielstwo jako proces odpowiednio spełniający potrzeby dziecka, zgodnie z obowiązującymi standardami kulturowymi, które mogą zmieniać się z pokolenia na pokolenie. Oczywiście, wszystkie dzieci potrzebują fizycznej opieki, zapewnienia właściwego odżywiania i poczucia bezpieczeństwa. Poza tymi podstawami na emocjonalne potrzeby dziecka składają się trzy komponenty dobrego rodzicielstwa:

- miłość, troska i zaangażowanie;

- kontrola/ konsekwentne ustawienie limitu;

- ułatwienie rozwoju (Hoghughi, 1998, s. 293-300).

Ważne jest, aby zdać sobie sprawę, że długoterminowe zapewnienie wszystkich trzech aspektów rodzicielstwa jest niezbędne do stworzenia warunków, aby dziecko dojrzało do bezpiecznego emocjonalnie, w pełni rozwiniętego i kompetentnego dorosłego.

Przyjrzyjmy się bliżej przedstawionym składnikom wychowania potomstwa. Pierwszy obejmuje miłość, troskę i zaangażowanie. Dzieci muszą czuć, że są kochane konsekwentnie i bezwarunkowo. Jeśli dziecko jest deprywowane emocjonalnie we wczesnym dzieciństwie, istnieje ryzyko, że rozwinie się „bezinteresowna psychopatia” Bowlby’ego, z całym upośledzeniem społecznym, co będzie miało wpływ zarówno na jednostkę, jak i na najbliższe społeczeństwo. Jeśli deprywacja jest częściowa, dziecko będzie narażone na zaburzenia relacji społecznych i emocjonalnych.

Drugim komponentem jest kontrola/stałe ustawienie limitów. Dotyczy to ustanawiania i egzekwowania granic, czego celem jest pomoc dziecku w jego kontaktach ze światem zewnętrznym. Granice muszą być ustanowione, aby pokazać, jakie zachowania są niedopuszczalne, z należytym uwzględnieniem etapów rozwojowych. Egzekwowanie wymaga wyraźnych działań w postaci nagród lub sankcji dyscyplinarnych, co zapewni konsekwencję w wyznaczonych ramach. Kontrola „wystarczająco dobra” wymaga ustanowienia rozsądnych granic, które są egzekwowane w konsekwentny, ale pełen miłości sposób, aby dziecko ostatecznie zaakceptowało rzeczywistość i nie przekraczało granic w swoim działaniu. Potomek uczy się żyć zgodnie z zasadami ogólnie akceptowalnymi. Jeśli granice są z natury nieuzasadnione lub kontrola jest stosowana niekonsekwentnie bądź zbyt karnie, będzie to szkodliwe dla rozwoju dziecka. Badania pokazują, iż wielu 
pospolitych przestępców było przedmiotem pobłażliwego braku dyscypliny przeplatanego nieprzewidywalnymi i nagłymi wybuchami ostrych zakazów i nakazów (Hoghughi, 1998, s. 293-300).

Trzeci aspekt rodzicielstwa polega na wspieraniu rozwoju dziecka, aby umożliwić mu pełne wykorzystanie jego potencjału. Dotyczy to każdej dziedziny funkcjonowania, od fizycznej i intelektualnej do moralnej, estetycznej i duchowej. Dziecko ma podstawową potrzebę bezpiecznej bazy, z której można badać swoje otoczenie. Opieka „wystarczająco dobra” obejmuje zapewnienie bogatej i zróżnicowanej stymulacji we wczesnym dzieciństwie, a następnie zaangażowanie i wsparcie dla potomka w późniejszych latach, aż do osiągnięcia dorosłości.

Odpowiedzialne rodzicielstwo, rozumiane jako bycie dobrym, kompetentnym rodzicem, z pewnością wymaga wiele poświęcenia. Rodzicielstwo zakłada postawę aktywną i oznacza podejmowanie pozytywnych działań przez rodziców w stosunku do dzieci. Używamy go w odniesieniu do relacji, procesu i grupy działań. Każdy, kto otacza dziecko opieką w jakimkolwiek otoczeniu, może być postrzegany jako część procesu rodzicielskiego (dziadkowie, przyjaciele, sąsiedzi, nauczyciele). Dlatego tak trudno jest dojść do jednoznacznego konsensusu w sprawie definicji odpowiedzialnego rodzicielstwa. Istotne jest rozpoznanie szerokiego kontinuum rodzicielstwa, którego dziecko potrzebuje, przechodząc przez dzieciństwo i dorastanie do dorosłości.

\section{PLANOWANIE RODZINY W DOBIE PRZEMIAN SPOŁECZNYCH}

Na początku warto ustalić, czym jest planowanie rodziny. Definicja z podręcznika Pielęgniarstwo we wspótczesnym położnictwie i ginekologii brzmi: „Planowanie rodziny to świadome i celowe przewidywanie struktury rodziny oraz liczby jej członków, uwarunkowane względami osobistymi, zdrowotnymi, socjalno-bytowymi i kulturowymi. Wiąże się ono z kontrolowaniem funkcji rozrodczych w oparciu o prawo małżonków/partnerów do posiadania dzieci tylko chcianych, urodzonych w warunkach uznawanych za optymalne dla prawidłowego ich rozwoju, wolnym wyborze odnośnie ich liczby i czasu. Rodzicielstwo świadome i odpowiedzialne oznacza, że do podstawowego zadania małżeństwa, jakim jest wydanie na świat potomstwa, angażuje się świadomość i poczucie odpowiedzialności obojga partnerów za życie, zdrowie i los ich dzieci” (Łepecka-Klusek, 2016, s. 49). W dobie przemian społecznych do planowania rodziny, a tym samym zapobiegania poczęciu wykorzystywane są najczęściej powszechne i łatwo dostępne środki chemiczne, nazywane metodami antykoncepcyjnymi. Żyjemy 
w państwie katolickim, a mimo to osoby praktykujące nie stosują zasad naturalnego planowania rodziny (NPR), które zazwyczaj kojarzone są z zawodnym kalendarzykiem. Metody naturalnego planowania rodziny oparte są na prawach biologii i mają podstawy naukowe, co wyjaśnia Światowa Organizacja Zdrowia (WHO). Metody naturalne są alternatywą dla mechanicznych lub farmakologicznych środków antykoncepcyjnych. $\mathrm{Z}$ medyczno-naukowego punktu widzenia WHO używa terminu NPR do opisania sposobu osiągnięcia lub odłożenia poczęcia - sposobu obserwacji występujących w sposób naturalny oznak i objawów faz płodności i niepłodności w czasie cyklu miesiączkowego. Osoby stosujące NPR dla odłożenia lub uniknięcia poczęcia dziecka powstrzymują się od współżycia w potencjalnie płodnych dniach. Tym, którzy dążą do poczęcia dziecka, NPR pomaga określić fazę płodności i przez to zwiększa prawdopodobieństwo poczęcia. $\mathrm{Z}$ definicji WHO wynika, że naturalne planowanie rodziny może być realizowane za pomocą metod rozpoznawania płodności, tj. metody kalendarzowej, metody termicznej, metody Billingsów, metod objawowo-termicznych opartych na prawach biologii, które mają podstawy naukowe. Jednym z najważniejszych osiągnięć badań naukowych nad płodnością jest możliwość obiektywnej oceny tych objawów. Dzięki temu można mówić o wysokiej skuteczności metod rozpoznawania płodności. Wzrostowe tendencje zainteresowania i rozpowszechniania metod naturalnego planowania rodziny mają swoje źródło w ogromnym postępie wiedzy w zakresie cyklicznych zmian płodności kobiety i wieloczynnikowych metodach wyznaczania terminu owulacji. Skuteczność tych metod w zastosowaniu praktycznym do regulacji poczęć osiągnęła poziom w pełni zadowalający (Troszyński, 2006, s. 32). Według danych WHO metody NPR mają następujące zalety: efektywność zarówno w planowaniu, jak i nieinicjowaniu poczęcia dziecka, brak działań niepożądanych, wzrost świadomości, wiedzy i zaufania do siebie, większe zaangażowanie się mężczyzny w planowanie rodziny i pogłębianie więzi małżeńskiej oraz brak nakładów finansowych. Warto też wspomnieć, iż stosowanie metod NPR umożliwia kobiecie dokładną obserwację swojego organizmu, a odpowiednio wypełnione karty obserwacji cyklu mają dużą wartość diagnostyczną i pomagają rozpoznać: cykle bezowulacyjne, niewydolność ciałka żółtego, wczesne stadium stanów zapalnych pochwy, charakter plamień i krwawień pozamiesiączkowych oraz torbiele jajników. Prowadzenie obserwacji pozwala też na dokładne ustalenie terminu porodu. Metody NPR mogą być godne polecenia dla par planujących poczęcie dziecka, wydłużających odstępy między kolejnymi narodzinami oraz dla tych, które nie planują już więcej potomstwa (Dmochowski, 2006, s. 105-109). Naturalne planowanie rodziny mieści 
się w programie WHO, o czym świadczy zalecenie numer 15 z 1987 roku: „Nauczanie metod rozpoznawania płodności powinno być włączone we wszystkie programy związane ze zdrowiem i wychowaniem, przeznaczone dla młodzieży i dorosłych, profesjonalistów i nieprofesjonalistów służby zdrowia”. Dorota Kornas-Biela (2004, s. 7-10) wśród psychologicznych trudności w akceptacji i stosowaniu NPR wymienia między innymi: brak dostatecznej wiedzy, mity dotyczące nieskuteczności i nienaukowości NPR, negatywny obraz siebie oraz własnego ciała, uzależnienie od doznań seksualnych, brak wsparcia ze strony współmałżonka, przykład własnych rodziców oraz otoczenia, niedojrzałość psychiczną i społeczną.

Występujące aktualnie zmiany w społeczeństwie dotyczące pluralizmu wartości, norm wzorów życia rodzinnego, łatwość dostępu do środków antykoncepcyjnych niosą wiele zagrożeń dla współczesnej rodziny, dlatego potrzebna jest ze strony rodziców świadomość celów i zadań rodziny w dziedzinie świadomego wychowania, rozumianego jako odpowiedzialne rodzicielstwo.

\section{RODZICIELSTWO A ZMIANY SPOŁECZNE}

Następnym etapem w życiu rodziców jest wychowanie potomka. Zdaniem Anny Śniegulskiej (2016, s. 96-101) „rodzicielstwo stanowi nie tylko etap rozwojowy czy płaszczyznę samorealizacji, ale również jest dla człowieka źródłem poczucia sensu życia, zadowolenia i radości. Przejawia się ono w pełnieniu roli matki i ojca, zaś najwłaściwszym środowiskiem do tego pozostaje rodzina oparta na wzajemnej miłości, szacunku, odpowiedzialności i dialogu”. Nie ma jednoznacznej odpowiedzi, jak być dobrym rodzicem, szczególnie gdy model życia rodzinnego i sposoby realizacji rodzicielstwa ulegają zmianom społeczno-kulturowym.

W dobie współczesnych przemian nie można pominąc tych, które dokonały się i wciąż ewoluują w obrębie życia małżeńsko-rodzinnego. Przejawem są alternatywne formy życia rodzinnego, takie jak: kohabitacja, pary bezdzietne, monoparentalność, rodziny światowe (Dobosz, 2016). Julie Taylor, Nick Spencer, Norma Baldwin doszli do wniosku, że rodzicielstwo można zrozumieć tylko w kontekście społecznym, w którym odbywają się interakcje wychowawcze i rozwój dziecka. Istnieją niezbite dowody z badań przeprowadzonych w USA i Wielkiej Brytanii na temat roli czynników społeczno-ekonomicznych w rodzicielstwie. Wydaje się, że mają one bezpośredni wpływ na zachowanie rodziców. Wzrost trudności ekonomicznych wiąże się ze zmniejszeniem opieki rodzicielskiej i wzrostem niespójnej dyscypliny obojga rodziców (Lempers, 1989, s. 25-39). Bezrobotni ojcowie wyka- 
zują mniej zachowań wychowawczych niż inni ojcowie. Niski dochód, w połączeniu z niskim poziomem postrzeganego wsparcia społecznego, wiąże się z większym prawdopodobieństwem karania dziecka przez rodzica (Harold-Goldsmith, 1988, s. 309-326). Różnorodność życia rodzinnego stanowi źródło zagrożeń dla odpowiedzialnego rodzicielstwa, dlatego poniżej zostaną przedstawione jedynie wybrane czynniki, które - zdaniem autorki - są najczęstszym zagrożeniem dla realizacji roli rodzica. Wskazanie czynników zagrażających stanowi jedynie zasygnalizowanie problemu.

\section{ZAGROŻENIA BĘDĄCE PRZESZKODĄ W REALIZACJI ODPOWIEDZIALNEGO RODZICIELSTWA}

Jedną z najbardziej znaczących przyczyn zakłócających właściwe relacje między rodzicielstwem a skutkami zdrowia dzieci jest status społeczno-ekonomiczny. Jest to również główny, dystalny element przyczynowej ścieżki do złych wyników u dzieci, których rodzicielstwo jest bardziej proksymalnym składnikiem.

Badania socjometryczne odzwierciedlają dominujący paradygmat społeczeństw, w których są podejmowane. W Wielkiej Brytanii i USA poszczególne rodziny i rodzice są postrzegani jako odpowiedzialni za zdrowie i socjalizację swoich dzieci. Indywidualność ta w postaci szkodliwych zachowań zdrowotnych ma wyższy priorytet niż czynniki społeczne, które mogą wpływać na indywidualne zachowania (Logan, 1996, s. 176-179). W tym kontekście status społeczno-ekonomiczny jest albo ignorowany, albo jego skutki są marginalizowane. Konsekwencją tego podejścia jest to, że status społeczno-ekonomiczny jest nieodpowiednio uwzględniany w wielu badaniach, które koncentrują się na indywidualnych cechach rodziców i ich wpływie na wyniki zdrowotne dzieci.

\section{a) Rozwody i separacja rodziców}

Badania naukowców Moniki Cockett i Johna Tripp'a (1998, s. 104-108) pokazują znaczące różnice w zakresie zachowania, samooceny i wyników wsparcia rodziny, ze szkodą dla dzieci $\mathrm{w}$ rodzinach uporządkowanych ponownie. Pomimo zgodnego procesu obie grupy cechują się odmiennym statusem społeczno-ekonomicznym. Rodziny uporządkowane ponownie są znacznie częściej narażone na otrzymywanie zasiłków państwowych, mieszkanie w wynajętym mieszkaniu, brak finansów oraz brak możliwości korzystania $\mathrm{z}$ samochodu. Autorzy sugerują, że niektóre $\mathrm{z}$ nich mogą być konsekwencją spadku 
dochodów związanych z rozpadem rodziny. Nie można też wykluczyć, że różnice te poprzedzają oddalenie się członków rodziny.

W Polsce wyniki badań GUS (2014) wskazują, że liczba rodzin niepełnych rośnie. W 2011 roku przeszło co czwarta rodzina była tworzona przez samotnego rodzica z dziećmi. W 2002 roku rodziców samodzielnie wychowujących dzieci było ok. 2 mln 30 tys., a w 2011 roku o prawie 473 tys. (ponad 23\%) więcej, czyli prawie $2 \mathrm{mln} 503$ tys. Około 2/3 tych rodzin mieszka w mieście. Wart odnotowania jest dynamiczny wzrost liczby ojców wychowujących samodzielnie dzieci z 178 tys. w 1988 roku, poprzez 232 tys. w 2002 roku, aż do prawie 329 tys. w 2011 roku - jakkolwiek w dalszym ciągu jest to najmniej liczny typ rodziny w Polsce. Rośnie, choć nie tak dynamicznie jak w przypadku samotnych ojców, liczba matek z dziećmi: w 2002 roku było ich 1 mln 798,3 tys., a w 2011 roku o $21 \%$ więcej, tj. 2 mln 147,3 tys.

\section{b) Bezrobocie}

Badania przeprowadzone w USA i Wielkiej Brytanii wskazują, że czynniki społeczno-ekonomiczne wydają się mieć bezpośredni wpływ na zachowanie rodziców. Niskie dochody w połączeniu z niskim poziomem wsparcia społecznego wiążą się z większym prawdopodobieństwem zachowań represyjnych ze strony rodzica wobec dziecka (Taylor, 2000, s. 113-200).

Alicja Kłos i Katarzyna Tomaszewska (2014, s. 187-198) zwracają uwagę na społeczne skutki bezrobocia, wśród których wymieniają następujące:

- izolacja społeczna bezrobotnych;

- frustracja i pesymistyczne nastroje;

- rozwój patologii;

- alkoholizm;

- przestępczość;

- pogorszenie stanu zdrowia psychofizycznego bezrobotnych;

- wzrost nastrojów radykalnych stanowiących podłoże dla skrajnych ruchów politycznych;

- niewykorzystany, nieproduktywny potencjał ludzki;

- spadek dochodów rodzin, rozszerzenie się społecznych kręgów ubóstwa;

- utrata kwalifikacji zawodowych;

- wzrost niezadowolenia społeczeństwa;

- utrata środków do życia nie tylko dla bezrobotnego, ale i dla całej jego rodziny, pogorszenie ich warunków do życia.

Autorki dostrzegają również pozytywne konsekwencje, a więc: 
- korzystny wpływ na konkurencyjność na rynku pracy;

- wzrost motywacji do kształcenia, do zwiększania nakładów na inwestycje w kapitał ludzki;

- możliwość realokacji zasobów ludzkich przy głębokich przemianach strukturalnych gospodarki z zawodów nieopłacalnych i nieefektywnych do zawodów nowoczesnych i efektywnych;

- walka z inflacją;

- wzrost motywacji pracowników do bardziej efektywnej i solidnej pracy oraz ograniczenie nadmiernej fluktuacji kadr.

Bezrobocie niesie poważne zagrożenia dla funkcjonowania rodziny, a tym samym spycha ją w krąg ubóstwa (Kaczyńska, 2004, s. 231).

\section{c) Ubóstwo}

Jak pisze Lisbeth Schorr: „ubóstwo jest największym zagrożeniem dla wszystkich. Ubóstwo rodzinne jest nieodmiennie skorelowane $\mathrm{z}$ urodzeniem w wieku szkolnym, niepowodzeniami w szkole i brutalnym przestępstwem" (Taylor, 2000, s. 115). Warto zaznaczyć, iż nie wykazano, że wysoki status społeczno-ekonomiczny jest czynnikiem ryzyka dla każdego z tych niekorzystnych rezultatów. Hoghughi i Speight (1998, s. 293-300) uznają, iż takie zachowania, jak maltretowanie i zaniedbywanie dzieci, opuszczenie dnia w szkole bez zgody opiekunów, niepowodzenia szkolne i przestępczość nieletnich są ściśle powiązane z deprywacją materialną.

Ponadto ubóstwo należy rozpatrywać w odniesieniu do jego wpływu na rodzicielstwo. Deprywacja materialna zwiększa ryzyko chorób i innych niekorzystnych skutków w całym cyklu życia. Wydaje się również, że niski status materialny ma znaczący wpływ na wyniki behawioralne i edukacyjne dzieci. Wśród dzieci w długotrwałym ubóstwie występuje większe ryzyko zarówno internalizacji, jak i eksternalizacji problemów behawioralnych oraz zmniejszenia ilorazu inteligencji w porównaniu z dziećmi żyjącymi w krótkotrwałym ubóstwie lub w bardziej zamożnych domach. Można wnioskować, że trudności ekonomiczne mają bezpośredni i pośredni wpływ na funkcjonowanie nastolatków. Zwiększona samotność oraz depresja u chłopców i dziewczynek bezpośrednio korelują z trudnościami ekonomicznymi, a pośredni wpływ wynika z ograniczonej opieki rodzicielskiej. Skutki trudności gospodarczych związanych z przestępczością i zażywaniem narkotyków są pośrednie (Taylor, 2000, s. 113-120).

Zdaniem Marty Komorskiej (2001, s. 143-152) podstawową przyczyną ubóstwa nie jest brak pieniędzy, lecz braki w szeroko rozumianej edukacji, w konsekwencji 
przyczyniające się do powielania negatywnych wzorców, a co się z tym wiąże marginalizacji społecznej. Dlatego tak ważne w polityce społecznej państwa jest zwrócenie szczególnej uwagi na realizację programów edukacyjnych mających na celu zarówno podniesienie poziomu i wyrównanie szans na zdobycie odpowiedniego wykształcenia całego społeczeństwa, jak i wprowadzenie programów z zakresu profilaktyki uzależnień i aktywizacji zawodowej.

Według GUS w 2017 r., podobnie jak w roku poprzednim, nastąpiła wyraźna poprawa sytuacji materialnej gospodarstw domowych w Polsce. Osiągnęły one wyższe dochody i poniosły większe wydatki. Wzrosła nadwyżka dochodów nad wydatkami, co dało większe możliwości oszczędzania.

\section{d) Konflikty małżeńskie}

Trudności ekonomiczne i materialne stają się częstą przyczyną konfliktów w małżeństwie. Badania Davida Johnsona (1990, s. 159-165) wskazują, iż samopoczucie dorosłych $\mathrm{w}$ gospodarstwie domowym zależy od rodzaju trudności gospodarczych i od relacji w związku małżeńskim. Zmiana roli w rodzinie, związana przykładowo $z$ utratą pracy ojca i wzrost znaczenia przypisywanego matce w podejmowaniu decyzji rodzinnych, mogą osłabić jedność rodziny i zwiększyć napięcie między małżonkami. Sytuacje stresowe w interakcjach rodzic-dziecko coraz częściej prowadzą do przymusowego rodzicielstwa, co powoduje wzrost problemów behawioralnych w dzieciństwie i opóźnień w przyszłości (Patterson, 1984, s. 1320-1327).

\section{WNIOSKI}

Podsumowując, zdaniem Taylor, Spencera i Baldwin społeczeństwo ma obowiązek podjęcia się roli rodzica. Badacze ci nie zgadzają się natomiast z perspektywą rodzicielstwa zagrożonego czynnikami negatywnie na nie wpływającymi (rozwody i separacja rodziców, bezrobocie, ubóstwo, konflikty małżeńskie). Rodzicielstwo to ojcostwo i macierzyństwo. Współczesny wizerunek ojca i matki podyktowany jest niewątpliwie przemianami społecznymi zachodzącymi na przestrzeni ostatnich lat. Niezmienna jednak pozostaje teza, iż rodzicielstwo jest najpełniejszym wyrażeniem się jednostek w rolach ojca i matki. Dzięki rodzicielstwu kobieta i mężczyzna odnajdują satysfakcję z życia i czują się spełnieni. Pełnione role pozwalają na wysoką ocenę jakości swojego życia (Sprawozdanie z III Międzynarodowej Konferencji Naukowej „Rodzicielstwo w różnych etapach rozwoju rodziny”, Kamień Śląski, 6-7 maja 2015 r.). Istotnym czynnikiem dla odpowiedzialnych rodziców jest 
ustawiczne budowanie więzi z dzieckiem od chwili narodzin. Codzienna, wieloletnia praca nad zaufaniem i szczerością wobec siebie - mimo wielu trudnych sytuacji związanych z dorastaniem - prowadzi do tego, że rodzicom łatwiej jest zrozumieć problemy i świat młodych ludzi. Istotą jest świadome przygotowanie się do bycia rodzicem, a następnie odpowiedzialne wychowanie młodego człowieka.

W ostatnich latach pojawiło się wiele różnorodnych problemów, które zapowiadają kryzys w naszym społeczeństwie. Istnieje coraz więcej dowodów na to, że rozpad rodziny w wyniku separacji, rozwodu lub samotnego wychowywania potomstwa ma szkodliwy wpływ na życie dzieci. Receptą na wymienione problemy jest odpowiedzialne podejście do wychowania nowego pokolenia.

Czynniki zagrażające odpowiedzialnemu rodzicielstwu zaburzają funkcjonowanie i strukturę rodziny, co bardzo negatywnie wpływa na rozwój dziecka. Zatem w odniesieniu do zmian zachodzących w społeczeństwie odpowiedzialne rodzicielstwo jest wyzwaniem i zadaniem. Poprzez swoje oddziaływanie na dziecko rodzice przekazują mu system wartości i norm, uczą ról i sposobu ich pełnienia w świecie nowych technologii i dostępu do środków zagrażających życiu człowieka. Rodzina, która podchodzi do rodzicielstwa odpowiedzialnie, potrafi świadomie dokonywać wyborów, podejmować decyzje i ponosić ich konsekwencje. Temu procesowi sprzyja pogłębianie przez rodziców wiedzy na temat wychowania i zagrożeń, jakie płyną ze strony najbliższego otoczenia. Wprowadzenie dziecka w system społeczny, przy zwróceniu uwagi na negatywne wpływy otaczającego świata, czyni odpowiedzialne rodzicielstwo doskonałym narzędziem do wszechstronnego rozwoju młodego pokolenia w obliczu szybkich zmian społecznych.

\section{BIBLIOGRAFIA}

BRĄGIEL, J. (2013). Znaczenie przemian społecznych dla współczesnego rodzicielstwa. W: J. BRĄGIEL, B. GóRNICKA (red.), Rodzicielstwo w kontekście współczesnych przemian społecznych (s. 13-23). Opole: Wydawnictwo Uniwersytetu Opolskiego.

Dmochowski, T., CerańsKa-Goszczyńska, H., Kinle, M. (2006). Zalety i trudności stosowania metod naturalnego planowania rodziny. W: M. TROSZYŃSKI (red.), Naturalne planowanie rodziny. Podręcznik dla nauczycieli naturalnego planowania rodziny. Warszawa: Bonami.

DoBosz, D., SŁANIA, K., Rodzicielstwo w mozaice przemian spoleczno-kulturowych-zagrożenia i perspektywy, [online:] https://www.researchgate.net/publication/317339713_Rodzicielstwo_w_mozai ce_przemian_spoleczno-kulturowych_-_zagrozenia_i_perspektywy (dostęp: 20.02.2019).

GóRnICKA, B., Sprawozdanie z III Międzynarodowej Konferencji Naukowej „Rodzicielstwo w różnych etapach rozwoju rodziny", Kamień Ślaski, 6-7 maja 2015 r.

GUS (2004). Gospodarstwa domowe i rodziny. Charakterystyka demograficzna. Narodowy Spis Powszechny Ludności i Mieszkań 2011. Warszawa. 
HAROld-Goldsmith, R., RAdin, N., EcCles, J.S. (1988). Objective and subjective reality: the impact of job loss and financial stress on fathers' behavior. Family Perspective, 22, 309-326.

HoghUGHI, M. (1998). Good enough parenting for all children - a strategy for a healthier society. Archives of Disease in Childhood, 78, 293-300.

JEDYNAK, S. (1990). Stownik etyczny (s. 175). Lublin: Wydawnictwo Uniwersytetu Marii CurieSkłodowskiej.

Johnson, D.R., BоотH, A. (1990). Rural economic decline and marital quality: a panel study of farm marriages. Family Relations, 39, 159-165.

KaCZYŃSKA, A. (2004). Wpływ bezrobocia na rodzinę. Prace Naukowe Akademii im. Jana Dlugosza w Częstochowie, Pedagogika, 13, 231.

KŁos, A., TomaszewSKA, K. (2014). Bezrobocie jako zjawisko społeczne stanowiące zagrożenie dla kształtowania się rynku pracy w Polsce. Spoleczeństwo. Edukacja. Język, 2, 187-198.

Komorska, M. (2001). Warunki życia rodzin dotkniętych ubóstwem. Annales Universitatis Mariae Curie-Sktodowska Lublin - Polonia, 26, 11, 143-152.

KornAs-Biela, D. (2004). Psychologiczne aspekty naturalnego planowania rodziny. Naturalne Planowanie Rodziny, 3-4, 7-10.

KromolickA, B. (2012). Jakość współczesnego rodzicielstwa. W: J. BRĄGIEL, B. GóRniCKA (red.), Rodzicielstwo $w$ kontekście wspótczesnych przemian społecznych (s. 39-51). Opole: Wydawnictwo Uniwersytetu Opolskiego.

Lempers, J.D., Clark-Lempers, D., Simon, RL. (1989). Trudności ekonomiczne, rodzicielstwo i cierpienie w okresie dojrzewania, Child Dev, 60, 25-39.

LogAn, S., SPEnCER, N.J. (1996). Smoking and other health related behaviours in the social and environmental context, Archives of Disease in Childhood, 74, 176-179.

ŁePECKA-KLuSEK, C. (2016). Pielęgniarstwo we współczesnym położnictwie i ginekologii. Podręcznik dla studiów medycznych (s. 49). Warszawa: PZWL Wydawnictwo Lekarskie.

Odpowiedzialność. (2000). W: Mała encyklopedia PWN (s. 593). Warszawa.

$O$ wyzwaniach bioetycznych, przed którymi stoi współczesny człowiek. Dokument przyjęty na 361. Zebraniu Plenarnym Konferencji Episkopatu Polski 5 marca 2013 r. w Warszawie.

Patterson, G.R., Stouthamer-Loeber, M. (1984). The correlation of family management practices and delinquency. Child Dev, 55, 1320-1327.

ŚNIEGULSKA, A. (2016). Edukacja do rodzicielstwa jako wyzwanie współczesności. Edukacja Technika - Informatyka, 4(18), 9-101.

TAYlor, J., SPEnCER, N., BAldwin, N. (2000). Social, economic, and political context of parenting. Archives of Disease in Childhood, 82, 113-120.

TRIPP, J.H., COCKETT, M. (1998). Parents, parenting and family breakdown. Archives of Disease in Childhood, 78, 104-108.

TroszyŃski, M. (2006). Naturalne planowanie rodziny. Podręcznik dla nauczycieli naturalnego planowania rodziny. Warszawa: Bonami.

\section{ODPOWIEDZIALNE RODZICIELSTWO \\ W KONTEKŚCIE ZMIANY SPOŁECZNEJ}

Streszczenie

Artykuł podejmuje problem odpowiedzialnego rodzicielstwa w perspektywie zmieniających się czasów i poglądów na wychowanie. Przeanalizowano w nim pojęcie odpowiedzialnego rodzicielstwa w świetle świadomego poczęcia dziecka oraz procesu wychowania. Ukazano również trudnoś- 
ci, na które narażony jest współczesny rodzic. Warto zwrócić uwagę na rozważania angielskich naukowców, którzy wskazują na komponenty dobrego rodzicielstwa wchodzące w skład emocjonalnych potrzeb dziecka. W tekście zaprezentowano również czynniki zagrażające postawie odpowiedzialnego rodzicielstwa. Do najważniejszych zostały zaliczone: rozwody i separacja rodziców, bezrobocie, ubóstwo, konflikty małżeńskie. Czynniki zagrażające odpowiedzialnemu rodzicielstwu zaburzają funkcjonowanie i strukturę rodziny, co bardzo negatywnie wpływa na rozwój dziecka. Zatem w odniesieniu do zmian zachodzących w społeczeństwie odpowiedzialne rodzicielstwo jest wyzwaniem i zadaniem.

Słowa kluczowe: odpowiedzialne rodzicielstwo; wychowanie; planowanie rodziny; zmiana społeczna; zagrożenia dla wychowania.

\section{RESPONSIBILITY PARENTHOOD \\ IN THE CONTEXT OF SOCIAL CHANGE}

\section{S u m m a r y}

The article addresses the problem of responsible parenting in the perspective of changing times and views on upbringing. It analyzed the concept of responsible parenthood in the light of the conscious conception of a child and the process of education. It also shows the difficulties that a modern parent is exposed to. It is worth paying attention to the considerations of English scientists who point to the components of good parenthood that are part of the emotional needs of the child. The text also presents factors threatening the attitude of responsible parenthood. The most important were: divorces and separation of parents, unemployment, poverty, marital conflicts. Factors threatening responsible parenthood disturb the functioning and structure of the family, which has a negative impact on the child's development. So in relation to changes in society, responsible parenthood is a challenge and a task.

Key words: responsibility parenthhood; education; planing of family; social change; factors threatening of education. 